\title{
Pembatalan Perjanjian Pengikatan Jual Beli (PPJB) Kondominium Akibat Wanprestasi
}

\author{
Oleh : Abel Agustian \\ Magang pada Kantor Notaris/PPAT Desi S Rachman, S.H., M.Kn \\ Kota Prabumulih-Sumatera Selatan \\ Email : abelagustian76@gmail.com
}

\begin{abstract}
Abstrak
Indonesia adalah negara dengan perkembangannya yang pesat, maka berkembang juga hal-hal di bidang property, misalnya peminat dalam jual beli kondominium atau yang lebih dikenal dengan istilah apartment.Namun seiring dengan banyaknya peminat dalam hal jual beli kondominium tersebut tak jarang juga menimbulkan berbagai problematika.Tujuan dari penelitian ini adalah untuk mengetahui hal-hal yang dapat menyebabkan batalnya akta Perjanjian Pengikatan Jual Beli (PPJB) atas Kondominium serta mengetahui akibat hukum apabila dilakukan pembatalan perjanjian.Kelalaian dapat merugikan salah satu pihak, akibatnya hal ini dapat menyebabkan dibatalkannya suatu perjanjian. Sedangkan akibat batalnya Perjanjian Pengikatan Jual Beli (PPJB) atas Kondominium yang dibuat dihadapan notaris karena wanprestasi dapat berupa denda, sanksi, pembatalanterhadap akta yang dibuat dihadapan notaris, dan pembayaran biaya perkara akibat pembatalan Perjanjian Pengikatan Jual Beli (PPJB). Dalam penelitian ini, penulis menggunakan metode penelitian yuridis normatif, dengan pendekatan konseptual, pendekatan perundang-undangan. Adapun hasil dari penelitian yang dapat penulis berikan dalam tesis ini adalah penyebab batalnya Perjanjian Pengikatan Jual Beli (PPJB) atas Kondominium dapat dikarenakan oleh adanya pihak yang tidak memberikan prestasi yang telah disepakati, sehingga menyebabkan kerugian disalah satu pihak.
\end{abstract}

Kata Kunci : Pembatalan PPJB, Wanprestasi

\begin{abstract}
Indonesia is a country with rapid development, so things that are developing in the property sector, such as those interested in buying and selling condominiums or better known as apartments.But along with the large number of enthusiasts in terms of buying and selling condominiums it is not uncommon to also cause various problems. The purpose of this study is to find out the things that can cause the cancellation of the Binding of Sale and Purchase Agreement (PPJB) for the Condominium and to find out the legal consequences if the agreement is canceled. Negligence can be detrimental to one party, as a result this can lead to the cancellation of an agreement. Whereas due to the cancellation of the Purchase Binding Agreement (PPJB) for condos made before a notary because defaults can be in the form of fines, sanctions, cancellation of the deed made before the notary public, and payment of case costs due to the cancellation of the Purchase Binding Agreement (PPJB). In this study, the author uses the normative juridical research method, conceptual aproach, statuta aproach. The results of the research that the author can provide in this thesis is the cause of the cancellation of the Binding
\end{abstract}


Agreement of Purchase (PPJB) for condos can be caused by a party that does not provide the achievements that have been agreed, thus causing harm to one party.

\section{Keywords: Cancellation of PPJB, Breach of Contract}

\section{Pendahuluan}

Tujuan pembangunan nasional adalah mewujudkan kesejahteraan lahir dan batin seluruh rakyat Indonesia secara adil dan merata, sebagai salah satu usaha untuk mengisi cita-cita perjuangan bangsa Indonesia bagi terwujudnya masyarakat adil dan makmur berdasarkan Pancasila dan Undang-Undang Dasar 1945. Salah satu unsur pokok kesejahteraan rakyat adalah terpenuhinya kebutuhan akan perumahan, yang merupakan kebutuhan dasar bagi setiap warga negara Indonesia dan keluarganya sesuai dengan harkat dan martabatnya sebagai manusia. ${ }^{1}$

Berdasarkan data dari Central Intelligence Agency (CIA) World Factbook 2004 Indonesia adalah negara keempat terpadat penduduk didunia, yaitu sekitar 268.074.600 penduduk yang tersebar diseluruh Indonesia. ${ }^{2}$ Dengan jumlah penduduk yang semakin meningkat, membuat pula kebutuhan akan ruang untuk hidup semakin meningkat. Namun, saat ini kesediaan tanah yang ada di Indonesia, terutama kota Besar semakin terbatas dan tidak bertambah, sedangkan penduduk di Indonesia semakin meningkat. salah satu perolehan tanah yang paling sering dijumpai adalah melalui jual beli.

Pembangunan rumah susunmerupakan salah satualternatif pemecahan masalahkebutuhanperumahan dan pemukiman terutama di daerahperkotaan yang jumlahpenduduknya terus meningkat, karena pembangunan rumah susun dapat mengurangi penggunaan tanah, membuat ruang-ruang terbuka kota yang lebih lega dan dapat digunakan sebagai suatu cara untuk peremajaan kota bagi daerah yang kumuh. ${ }^{3}$

Dewasa ini, jual beli satuan rumah susun/ apartemen yang belum selesai dibangun semakin meningkat, bahkan tidak jarang jual beli satuan rumah susun/ apartemen ini dilakukan pada saat rumah susun masih berada dalam perencanaan. Pelaksanaan jual beli satuan rumah susun/ apartemen yang seperti ini dilakukan dengan cara memesan terlebih dahulu atas unit yang akan dibeli dengan surat pemesanan. seperti yang terjadi pada pembangunan satuan rumah susun yang ada di salah satu kota Besar yang ada di Indonesia. Para pihak developer telah menjual condominium ini kepada masyarakat dengan cara membayarkan sedikit uang sebagai tanda jadi atau sebagai bukti keseriusan calon pembeli, setelah itu dilanjutkan dengan perjanjian awal yaitu Surat Pemesanan Pemilihan Unit atau disebut SPPU. SPPU merupakan kesepakatan awal antara calon pengembang dan pemesan, setelah pemesan membayar 20\% (dua puluh persen) dari harga

\footnotetext{
${ }^{1}$ Adrian Sutedi, Hukum Rumah Susun \& Apartemen,Sinar Grafika,Jakarta Timur 2010.hlm.158

2 Diakses pada tanggal 01 Oktober 2019 di Kota Jambi, pada Pukul 12.00 WIB dengan url: https://id.wikipedia.org/wiki/Daftar_negara_menurut_jumlah_penduduk

${ }^{3}$ Arie. S. Hutagalung, Kondominium Dan Permasalahnya (Edisi Revisi), BadanPenerbitkan Fakultas Hukum UI,Jakarta, 2017, hlm 2
} 
jual yang disepakati, kemudian dilanjutkan dengan perjanjian perikatan pendahuluan atau yang lebih dikenal dengan sebutan perjanjian perikatan jual beli (PPJB). ${ }^{4}$ Ketentuan pemesan harus membayar sebesar 20\% terlebih dahulu ini telah diatur dalam Pasal 43 ayat 1 UndangUndangNomor 20 Tahun 2011 tentang Rumah Susun (UURS) bahwa rumah susun yang prosespembangunannya belum selesai dapat melakukan proses jual beli di hadapan Notaris melalui PPJB, akan tetapi harus memenuhi persyaratan kepastian akan status kepemilikan tanah, kepemilikan IMB, ketersediaan prasarana sarana, utilitas umum keterbangunan paling sedikit $20 \%$ (dua puluh persen) dan hal yang diperjanjikan.

Di Indonesia, penjualan dengan sistem Pre Project Selling dilakukan dengan membuat Perjanjian Pengikatan Juali Beli (PPJB). Para pihak membuat PPJB yang dibuat dihadapan notaris.Isi dari PPJB adalah syarat-syarat perjanjian yang mengatur antara hak dan kewajiban serta tanggung jawab masing-masing pihak dalam perjanjian. Dengan dibuatnya perjanjian pengikatan jual beli haknya pembeli sudah ada dan dapat terlindungi, tinggal menunggu proses pemecahan selesai dan setelah itu diproses balik nama keatas nama diri sendiri (pembeli). ${ }^{5}$

Setelah akta PPJB dibuat, selanjutnya perjanjian ini dilanjutkan dengan pembuatan Akta Jual Beli (AJB). AJB ini merupakan suatu akta otentik yang dibuat oleh PPAT sebagai bukti untuk peralihan hak atas tanah dan bangunan. AJB inilah yang akan digunakan dalam pengajuan balik nama atau pendaftaran peralihan hak ke kantor pertanahan setempat. Dengan selesainya proses balik nama atau pendaftaran peralihan hak, maka hak yang melekat pada tanah dan bangunan telah berpindah dari penjual kepada pembeli.

Pasal 15 Undang-Undang Nomor 2 Tahun 2014 tentang Perubahan atas Undang-Undang Nomor 30 Tahun 2004 tentang Jabatan Notaris menjelskan bahwa Notaris adalah pejabat umum yang satu-satunya berwenang untuk membuat akta. Notaris dalam posisinya sebagai pejabat umum dan sekaligus sebagai profesi bertugas membuat alat bukti tertulis berupa akta otentik yang dapat mewujudkan pembuktian hukum yang kuat dan sempurna. ${ }^{6}$

Tujuan dibuatnya PPJB untuk mengamankan kepentingan pengembang dan pemesan satuan rumah susun/ apartemen, maka oleh pemerintah dirasakan perlunya pengaturan secara khusus mengenai PPJB satuan rumah susun/ apartemen dan penerapan pedoman PPJB satuan rumah susun/ apartemen perlu pengawasan dan pengendalian yang dilakukan oleh Badan Kebijaksanaan dan Pengendalian Pembangunan Perumahan dan Permukiman Nasional melalui BadanPengendalian Pembangunan Perumahan dan Permukiman Daerah, yang kemudian dituangkan dalam Keputusan Menteri Negara Perumahan Rakyat Republik Indonesia Nomor 11/KPTS/1994 disebut Kepmenpera Nomor 11 Tahun 1994 tentang Pedoman Perikatan Jual Beli Satuan Rumah Susun, dengan diberlakukannya Kepmenpera Nomor 11 Tahun 1994 tersebut,

\footnotetext{
${ }^{4}$ Sugiharti,op.cit.,

${ }^{5}$ Pingkan Martina Manueke, 'Jual Beli Tanah Yang Mempunyai Sertifikat Hak Atas Tanah Menurut Peraturan Pemerintah Nomor 24 Tahun 1997', Lex Privatum, VI (2018).hlm.158. 67.

${ }^{6}$ Aman, "Perlindungan Hukum Bagi Notaris dalam Melaksanakan Jabatannya", Recital Review, Vol 1 No. 2, Juli 2019, hlm.
} 
maka setiap adanya perikatan jual beli satuan rumah susun wajib mengikuti pedoman yang ditetapkan dalam Kepmenpera Nomor 11 Tahun 1994 tersebut. $^{7}$

Didalam hal jual beli condominium yang terdapat di Kota Palembang, pembeli sudah melakukan pembayaran meskipun unit condominium tersebut belum selesai dibuat.Hingga saat ini pembangunan kondominium tersebut belum selesai, artinya kesepakatan antara pihak developer dan pembeli menimbulkan kerugian terhadap pembeli dikarenakan pembeli belum bisa mendapatkan haknya untuk menikmati condominium yang telah mereka beli.

Perjanjian tersebut tidak berakhir karena salah satu pihak baik penjual maupun pembeli meninggal dunia, tetapi temurun ke ahli warisnya atau yang mendapatkan hak dari padanya. Diperlukan proses dan waktu kurang lebih 2 sampai 3 bulan, dan sebelum sertifikat pemecahan selesai, tidak dapat dilakukan jual beli dihadapan PPAT, untuk itu dibuatkan perjanjian pengikatan jual beli dan kuasa supaya antara penjual dan pembeli dapat melakukan transaksi jual beli. Apabila harga jual beli objek tersebut seluruhnya telah dibayar lunas oleh pembeli kepada penjual, memberi kuasa kepada pembeli dengan hak untuk menyerahkan kekuasaan ini kepada pihak lain, untuk dan atas nama penjual menjalankan hak dan kepentingan penjual untuk melakukan segala tindakan, baik yang berupa pengurusan maupun yang berupa kepemilikan. ${ }^{8}$

Jika membaca Kepmenpera Nomor 11 Tahun 1994 mengenai komitmen pengembang dalam serah terima bangunan, bahwa pengembang berkewajiban menyelesaikan pembangunan dengan jangka waktu 120 (seratus dua puluh) kalender, dihitung sejak tanggal rencana penyerahan apartemen tersebut, apabila tidak terlaksana sama sekali, maka PPJB batal demi hukum.

Hal kebatalan didalam teori hukum dapat dibagi menjadi dua hal, yaitu batal demi hukum dan dapat dibatalkan. Disebut batal demi hukum apabila kebatalannya terjadi karena undang-undang, Pada umumnya ketentuan-ketentuan yang berhubungan dengan kebatalan ini adalah perjanjian-perjanjian obligator. Misalnya perjanjian dengan kausa yang tidak halal dan hibah antara suami dan istri.Batal demi hukum berakibat bahwa perbuatan hukum yang bersangkutan oleh hukum dianggap tidak pernah terjadi. Dapat dibatalkan, mengandung arti bahwa perjanjian itu akan dibatalkan atau tidak, sepenuhnya terserah pada para pihak yang membuat perjanjian. Dapat dibatalkan baru mempunyai akibat hukum setelah ada putusan hakim yang membatalkan perbuatan hukum tersebut. Sebelum ada putusan, perbuatan hukum tersebut tetap berlaku. ${ }^{9}$

\footnotetext{
${ }^{7}$ Helen Taurusia, Perikatan Jual Beli Satuan Rumah Susun Berdasarkan Kepmenpera Nomor 11 Tahun 1994 , http://www.hukumproperti.com, diakses tanggal 2 September 2019 pukul 11.00 WIB

${ }^{8}$ Pingkan Martina Manueke, Op.Cit., hlm. 154.

${ }^{9}$ Nindyo Pramono, 'Problematika Putusan Hakim dalam perkara Pembatalan Perjanjian," Membar Hukum Volume 22 Nomor 1 (Juni 2010), hlm. 230.
} 
Dalam hal Pembatalan perjanjian yang dilakukan di depan Pengadilan dapat terlaksana pada saat perjanjian itu terjadi, ada salah satu pihakyang belum cakap untuk melakukan suatu perbuatan hukum, perjanjian disetujui karena di bawah ancaman atau dikarenakan adanya kekhilafan mengenai objek perjanjian. Dengan demikian, pihak yang merasa dirugikan dapat memohon kepada Hakim agar perjanjian itu dapat dibatalkan. Selanjutnya berkenaan dengan sanksi hukum pembatalan yang dilakukan di depan pengadilan berlaku setelah adanya putusan Pengadilan yang inkracht van gewijzde dan menyatakan bahwa pembatalan atas perjanjian peralihan hak atas tanah yang dituangkan dalam suatu akta otentik tersebut.

Dari penjelasan sebelumnya, dapat diketahui bahwa syarat sahnya perjanjian ini bersifat kumulatif. Artinya seluruh persyaratan tersebut harus dipenuhi agar perjanjian itu menjadi sah, dengan konsekuensi tidak dipenuhi satu atau lebih syarat dimaksud akan menyebabkan perjanjian tersebut dapat diganggu gugat keberadaannya (batal/neitig atau dapat dibatalkan/vernietigbaar). ${ }^{10}$

Dari derivasi uraian tersebut diatas, penulis bermaksud untuk menyusun tulisan dalam bentuk tesis yang berjudul Pembatalan Perjanjian Pengikatan Jual Beli Kondominium Akibat Wanprestasi.Penelitian ini dilakukan dengan tipe penelitian yuridis normatif. Penelitian hukum normatif adalah penelitian bahan hukum yang meneliti bahan hukum baik data primer dan data sekunder dengan mempelajari sumber-sumber atau bahan tertulis berupa buku-buku, artikel, koran dan majalah dengan membaca, menafsirkan, membandingkan serta menerjemahkan dari berbagai sumber yang berhubungan dengan akibat hukum bagi Notaris dalam hal pembatalan jual beli condominium setelah pembuatan PPJB. ${ }^{11}$

\section{Permasalahan}

Berdasarkan latar belakang di atas maka permasalahannya adalah:

1. Apakah penyebab batalnya Akta perjanjian Pengikatan Jual Beli Atas Condominium yang dibuat dihadapan notaris?

2. Bagaimana akibat hukum apabila dilakukan pembatalan Akta perjanjian Pengikatan Jual Beli Atas Condominium yang dibuat dihadapan notaris?

\section{Pembahasan}

\section{Penyebab Batalnya Akta Perjanjian Pengikatan Jual Beli (PPJB) Atas Condominium Yang} Dibuat Dihadapan Notaris

Perjanjian adalah suatu peristiwa dimana seorang berjanji kepada seorang lain atau dimana dua orang itu saling berjanji untuk melakukan suatu hlm. Perjanjian juga telah diatur didalam Pasal 1313 KUH Perdata yang menyatakan bahwa perjanjian merupakan suatu perbuatan dengan mana satu orang atau lebih mengikatkan dirinya terhadap satu orang lain atau

\footnotetext{
${ }^{10}$ Lintang Yudhantaka, “Keabsahan Kontrak Jual Beli Rumah Susun dengan Sistem Pre Project Selling,” Yuridika Volume 32 Nomor 1 (Januari 2017), hlm. 89.

${ }^{11}$ Ibid.
} 
lebih. Perjanjian merupakan suatu perbuatan hukum yang dapat menimbulkan akibat hukum.Dengan adanya perjanjian, maka diantara pihak yang telah mengikatkan diri tersebut timbul suatu hak dan kewajiban yang harus ditepati.

Suatu perjanjian dapat dilaksanakan apabila memenuhi unsur dan syarat sahnya suatu perjanjian sebagaimana ternyata didalam Pasal 1320 KUH Perdata yaitu, Sepakat mereka yang mengikatkan dirinya, Kecakapan untuk membuat suatu perikatan, Suatu hal tertentu, dan Suatu sebab yang halal.

Adanya kata sepakat antara pihak dalam perjanjian mengandung makna bahwa para pihak yang membuat perjanjian telah sepakat atau ada persesuaian kemauan atau saling menyetujui kehendak masing-masing, yang dilahirkan oleh para pihak dengan tidak ada paksaan, kekeliruan dan penipuan. ${ }^{12}$

Dengan timbulnya hak dan kewajiban diantara para pihak, maka melalui peristiwa hukum ini muncul suatu hubungan antara dua orang tersebut yang dinamakan perikatan. Berdasarkan Pasal 1233 KUH Perdata, perikatan dilahirkan baik karena perjanjian ataupun undang-undang. Selanjutnya Pasal 1234 menyatakan bahwa tiap-tiap perikatan adalah untuk memberikatan sesuatu, untuk berbuat sesuatu atau tidak berbuat sesuatu.

Dalam perikatan yang timbul diantara para pihak, maka timbul suatu hak dan kewajiban. Adapun hak dari pembeli adalah untuk mendapatkan barang yang dibeli dari penjual sedangkan kewajiban dari pembeli adalah memberikan uang yang telah disepakati sebagai harga dari suatu barang. Sebaliknya, hak dari penjual adalah menerima uang dari pembeli yang telah menyetujui harga barang yang akan dibeli dan kewajiban dari penjual adalah memberikan barang yang telah dibeli.

Di era sekarang ini, jual beli selalu ada dimanapun dan kapanpun.Misalnya jual beli di bidang kuliner, jual beli di bidang fashion, sampai dengan jual beli di bidang property.Berbicara mengenai property, di kota-kota besar banyak sekali terjadi perikatan dalam jual beli property.Contohnya jual beli apartemen, rumah, rumah susun, condominium, dan masih banyak lagi.Dalam hal jual beli condominium, terdapat penjual sebagai pihak yang menjual condominium dan konsumen sebagai pihak yang membeli condominium.

Di Indonesia sendiri kondominium diatur didalam Undang-Undang Nomor 20 Tahun 2011 tentang Rumah susun. Kondominium di Indonesia lebih dikenal dengan hak guna bangunan atas rumah susun, Berdasarkan Pasal 1 ayat 1 Undang-Undang Nomor 20 Tahun 2011 tentang Rumah susun, Rumah susun adalah bangunan gedung bertingkat yang dibangun dalam suatu lingkungan yang terbagi dalam bagian-bagian yang distrukturkan secara fungsional, baik dalam arah horizontal maupun vertikal dan merupakan satuan-satuan yang masing-masing dapat dimiliki dan digunakan secara terpisah, terutama untuk tempat hunian yang dilengkapi dengan bagian bersama, benda bersama, dan tanah bersama. Condominium adalah milik bersama dan daerah yang dikuasai bersama-sama,gedung bertingkat dengan fasilitas yang lebih mewah.

${ }^{12}$ Fauzan Aziman Alhamidy, Isis Ikhwansyah, Zainal Muttaqin, "Perlindungan Hukum Konsumen Akibat Pencabutan Izin Mendirikan Bangunan Apartment”, Recital Review, Vol 2 No. 1, 2020, hlm. 93. 
Menurut wawancara yang dilakukan penulis kepada Bapak Michael (Developer dari PT. AJH yang berkedudukan di Kota Palembang), kondominium adalah apartemen yang dijual untuk dimiliki oleh masing-masing penghuni. Pemilik dari apartemen tersebut berhak untuk memakai, menyewa, dan menjual kepada orang lain. Namun, terdapat perbedaan dengan apartemen yaitu merujuk ke hunian vertical yang disewakan pemiliknya kepada orang lain. Pemilik dari apartemen tersebut berhak untuk tinggal, namun tidak berhak untuk menyewakan, apalagi untuk menjualnya kepada orang lain. ${ }^{13}$

Di kota besar seperti Jakarta, Bogor, Depok, Tangerang, dan Bekasi (Jabodetabek), peminat condominium sangat banyak. Namun, berdasarkan data Lembaga Konsultan Properti Jones Lang Lasalle (JLL) tingkat penjualan pada kuartal kedua tahun 2018 menyusut $1 \%$ (satu persen) disbanding dengan penjualan kuartal pertama. Berdasarkan data JLL tercatat total condominium yang terjual sepanjang kuartal II 2018 sebanyak 900 unit, sementara pengembang menawarkan 309 unit kondominium baru sepanjang waktu tersebut. ${ }^{14}$

Berdasarkan Pasal 3 Peraturan Menteri PUPR Nomor 11/PRT/M/2019 tentang Sistem PPJB Rumah, dalam kegiatan pemasaran pelaku pembangunan dapat melakukan hal sebagai berikut: ${ }^{15}$

1. Pelaku pembangunan dapat melakukan Pemasaran Rumah tunggal atau Rumah deret pada saat dalam tahap proses pembangunan.

2. Pelaku pembangunan dapat melakukan Pemasaran Rumah Susun sebelum pembangunan dilaksanakan.

3. Pemasaran sebagaimana dimaksud pada ayat (1) dan ayat (2) harus memuat informasi

Pemasaran yang benar, jelas, dan menjamin kepastian informasi mengenai perencanaan dan kondisi fisik yang ada.

Proses pemasaran dan jual beli condominium pada saat bangunan belum jadi, telah diatur dalam Pasal 42, Pasal 43 dan Pasal 44 Undang-Undang Nomor 20 Tahun 2011 tentang Rumah Susun (UU Rusun). Pasal 42 UU Rusun diatur bahwa pemasaran dapat dilakukan sebelum pembangunan rumah susun dilaksanakan.Pasal 43 ayat (3) diatur bahwa ketika pemasaran dilakukan sebelum pembangunan rumah susun segala sesuatu yang dijanjikan oleh pelaku pembangunan dan/atau agen pemasaran mengikat sebagai perjanjian pengikatan jual beli (PPJB) bagi para pihak. Pasal 43 ayat (2) Perjanjian Pengikatan Jual Beli (PPJB) dilakukan setelah memenuhi persyaratan kepastian atas $:{ }^{16}$

1. Status Kepemilikan Tanah;

\footnotetext{
${ }^{13}$ Wawancara kepada Bapak Michael pada tanggal 2-12-2019 di Kota Palembang.

14 Dinda Audriene Muthmainah, Kuartal II, Penjualan Condominium di Jabodetabek Melesu, diaksespadatanggal28Januari2020padahttps://www.cnnindonesia.Com/ekonomi/2018071816024992-315126/kuartal-iipenjualankondominium-di-jabodetabek-melesu

${ }^{15}$ Pasal 3 Peraturan Menteri PUPR Nomor 11/PRT/M/2019 tentang Sistem PPJB Rumah

${ }^{16}$ Pasal 42 dan Pasal 43 Undang-Undang Nomor 21 Tahun 2011 tentang Rumah Susun.
} 
2. Kepemilikan IMB;

3. Ketersediaan Prasarana, Sarana, Dan Utilitas Umum;

4. Keterbangunan Paling Sedikit 20\% (Dua Puluh Persen); dan

5. Hal Yang Diperjanjikan

Pasal 43 Ayat (2) diatur bahwa proses jual beli unit Satuan Rumah Susun (Sarusun) sebelum pembangunan rumah susun selesai, dapat dilakukan melalui Perjanjian Pengikatan Jual Beli (PPJB) yang dibuat di hadapan notaris. Proses pembelian unit satuan rumah susun Condominium juga diawali dengan Surat Pemesana lalu dibuat Perjanjian Pengikatan Jual Beli (PPJB) baik itu di hadapan notaris maupun bawah tangan. PPJB merupakan perjanjian pengikatan dalam jual beli unit condominium antara pihak penjual dan pihak pembeli, dikarenakan adanya halangan-halangan sebelum dilaksanakan perjanjian pokok. Halanganhalangan tersebut antara lain adanya syarat yang belum terpenuhi, seperti obyek jual beli yang diperjanjikan belum selesai dibangun, sertipikat yang masih dalam proses, proses pendaftaran peralihan hak maupun sedang proses pemecahan/pertelaan di Kantor Pertanahan, serta pajak yang belum lunas, dan/atau pembayaran yang belum lunas.

Sebelum dilakukan pembuatan PPJB dihadapan notaris, biasanya para pihak pemasaran atas condominium memberikan surat Pra-PPJB kepada konsumen yang telah setuju untuk membeli condominium. Surat pra-PPJB ini merupakan surat yang berisi perjanjian saat pengembang (developer) masih memasarkan unit condominiumnya. Aturan ini juga disebut dengan surat pesanan.

Surat pesanan ini minimal memuat nama sarusun atau nomor bangunan yang dipesan; nomor lantai dan tipe sarusun; luas sarusun; harga jual sarusun; ketentuan pembayaran uang muka; spesifikasi bangunan; tanggal selesainya pembangunan rumah susun; ketentuan mengenai pernyataan dan persetujuan menerima persyaratan dan ketentuan yang ditetapkan; dan menandatangani dokumen yang dipersiapkan pelaku pembangunan rumah susun. Surat pesanan dilampiri dengan gambar yang menunjukan letak pasti sarusun yang dipesan serta ketentuan tahapan pembayaran. ${ }^{17}$

Selanjutnya, dalam jangka waktu 30 hari kalender setelah penandatanganan surat pemesanan, pemesan dan pelaku pembangunan (pengembang) harus menandatangani akta PPJB dan memenuhi kewajiban sebagaimana ditetapkan dalam akta PPJB. Apabila waktu yang ditentukan belum menandatangani akta PPJB, maka akibat kelalaian pemesan, pelaku pembangunan dapat tidak mengembalikan uang pesanan.Sebaliknya, akibat kelalaian pelaku pembangunan, uang pesanan dapat dikembalikan 100 persen. Namun, surat praPPJB ini tidak dapat dibuat dihadpaan notaris, meskipun perjanjian pra-PPJB mengikat pihak developer (pengembang) dan konsumen terkait jual beli atas condominium.

\footnotetext{
${ }^{17}$ Aida Mardatillah, Pra-PPJB yang dibuat dengan maksud mendahului PPJB tidak dapat dibuat di hadapan notaris, diakses pada tanggal 22 Januari 2020, pada laman https://www.hukumonline.com/berita/baca/lt5a20010d8395b/kenali-model-akad-inisebelum-beli-apartemen/
} 
PPJB atas condominium yang telah dibuat oleh para pihak dihadapan notaris berakhir apabila telah dibuat suatu akta jual beli atas condominium dihadapan PPAT di wilayah mana obyek jual beli tersebut berada.

PPJB dalam prakteknya dimungkinkan untuk dibatalkan secara sepihak oleh salah satu pihak atau atas kesepakatan kedua belah pihak.Selain itu juga PPJB dapat pula dibatalkan oleh suatu keputusan pengadilan. PPJB atas condominium yang telah dibuat oleh para pihak dapat dilakukan pembatalan apabila salah satu pihak tidak melaksanakan apa yang menjadi kewajibannya.

Berdasarkan Pasal 13 Peraturan Menteri PUPR Nomor 11/PRT/M/2019 tentang Sistem PPJB Rumah yaitu : ${ }^{18}$

1. Dalam hal pembatalan pembelian Rumah setelah penandatanganan PPJB karena kelalaian pelaku pembangunan maka seluruh pembayaran yang telah diterima harus dikembalikan kepada pembeli.

2. Dalam hal pembatalan pembelian Rumah setelah penandatanganan PPJB karena kelalaian pembeli maka:

a. jika pembayaran telah dilakukan pembeli paling tinggi $10 \%$ (sepuluh persen) dari harga transaksi, keseluruhan pembayaran menjadi hak pelaku pembangunan; atau

b. jika pembayaran telah dilakukan pembeli lebih dari 10\% (sepuluh persen) dari harga transaksi, pelaku pembangunan berhak memotong $10 \%$ (sepuluh persen) dari harga transaksi.

Di Indonesia sendiri terdapat beberapa permasalahan dalam hal jual beli condominium. Biasanya permasalahan yang terjadi antara developer dengan pembeli karena adanya wanprestasi. Namun, jika dilihat dari asas kemitraan yang memberikan landasan agar penyelenggaraan rumah susun (condominium) dilakukan oleh pemerintah dan pemerintah daerah dengan melibatkan pelaku usaha dan masyarakat dengan prinsip saling mendukung sebagaimana dimaksud dalam penjelasan Pasal 2 huruf m UURS. Prinsip saling mendukung antara pengembang dan masyarakat selaku konsumen termasuk bagaimana bentuk kesepaktan yang dibuat terkait dengan kepemilikan unit condominium. ${ }^{19}$

Permasalahan yang terjadi antar para pihak jual beli condominium dapat berakibat pada pembatalan PPJB yang dilakukan oleh pembeli karena pembeli merasa dirugikan oleh pihak developer. Hal ini dilandasi karena berhentinya pembangunan condominium yang ada di salah satu kota di Indonesia.

Berdasarkan Pasal 1381 KUH Perdata yang menyatakan bahwa dengan berakhirnya perikatan adalah selesainya atau hapusnya sebuah perikatan yang diadakan antara dua pihak, yaitu pihak kreditor dan debitor tentang suatu hlm. Pihak kreditor adalah pihak atau orang yang

\footnotetext{
${ }^{18}$ Pasal 13 Peraturan Menteri PUPR Nomor 11/PRT/M/2019 tentang Sistem PPJB Rumah

${ }^{19}$ Riki Perdana Raya Waruwu, Mengakhiri Konflik Konsumen Pengembang Apartemen, diakses pada tanggal 01 Februari 2020 pada laman https://www.hukumonline.com/berita/baca/lt599ab7314a829/mengakhiri-konflik-konsumen-pengembangapartemen-oleh--riki-perdana-raya-waruwu/
} 
berhak atas suatu prestasi. Sedangkan debitor adalah pihak yang berkewajiban untuk memenuhi prestasi. $^{20}$

Didalam jual beli condominium yang mengakibatkan batalnya PPJB akibat adanya wanprestasi yaitu PPJB batal dikarenakan pihak developer tidak mengindahkan bentuk perjanjian yang telah disyaratkan didalam UU.

Sehingga pihak developer dapat dikatakan wanprestasi terhadap apa yang telah diperjanjikannya kepada pembeli unit condominium. Wanprestasi itu sendiri adalah tindakan debitur (Yakni pihak yang berjanji untuk melakukan sesuatu) tidak memenuhi prestasi yang telah disepakati dalam perjanjian. Prestasi yang dimaksud dalam hal ini adalah suatu hal yang wajib dipenuhi oleh debitur. ${ }^{21}$

Namun, terdapat juga pembatalan PPJB yang dilakukan oleh developer (pengembang condominium) dikarenakan pembeli lalai memenuhi prestasinya dalam membayar kewajiban mereka sebagai penjual, sehingga developer membatalkan PPJB atas dasar kewenangan didalam PPJB. Pembeli seharusnya mentaati kesepakatan yang tertuang didalam PPJB karena pada dasarnya PPJB atas condominium merupakan perjanjian yang mengikat kedua belah pihak.

Jadi, penyebab batalnya PPJB atas condominium akibat wanprestasi dapat terjadi karena pihak developer ataupun konsumen. Sehingga ada beberapa penyebab yang mengakibatkan pembatalan PPJB atas condominium dikarenakan wanprestasi adalah :

1. Pihak developer tidak melakukan kewajibannya untuk memberikan prestasi, misalnya tidak memberikan serah terima kunci pada saat waktu yang telah ditentukan.

2. Konsumen lalai dalam melakukan kewajibannya untuk membayar unit condominium yang telah disepakati didalam PPJB.

3. Konsumen melakukan pembayaran namun tidak sebagaimana diperjanjikan didalam PPJB.

Berdasarkan Pasal 1243 KUH Perdata bahwa "Penggantian biaya ganti rugi dan bunga karena tidak dipenuhinya suatu perikatan, barulah mulai diwajibkan apabila debitur setelah dinyatakan lalai memenuhi perikatannya, tetap melalaikannya atau jika sesuatu yang harus diberikan atau dibuatnya dalam tenggang waktu tertentu telah dilampauinya”.

Maksudnya adalah berada dalam keadaan lalai adalah peringatan atau pernyataan dari kreditur tentang saat selambat-lambatnya debitur wajib memenuhi prestasi. Apabila saat ini dilampauinya, maka debitu ingkarjanji (wanprestasi). ${ }^{22}$

Dalam hal terjadinya wanprestasi, maka pihak lain sebagai pihak yang menderita kerugian dapat memilih antar beberapa kemungkinan, yaitu :

1. Pihak yang dirugikan menuntut pelaksanaan perjanjian

2. Pihak yang dirugikan menuntut ganti rugi

\footnotetext{
${ }^{20}$ Salim HS, Op. Cit. hlm. 187.

${ }^{21}$ Lily, Op. Cit.

${ }^{22}$ Mariam Darus Badrulzaman, Op. Cit. hlm. 19.
} 
3. Pihak yang dirugikan menuntut pelaksanaan perjanjian disertai ganti rugi

4. Pihak yang dirugikan menuntut pembatalan perjanjian

5. Pihak yang dirugikan menuntut pembatalan perjanjian disertai dengan ganti rugi.

Wanprestasi yang mengakibatkan batalnya jual beli atas condominium yang telah dilakukan PPJB, maka pihak yang merasa dirugikan baik pihak developer ataupun konsumen dapat melakukan hal-hal tersebut diatas.

\section{Akibat Hukum Apabila Dilakukan Pembatalan Akta Perjanjian Pengikatan Jual Beli (PPJB) Atas Condominium Yang Dibuat Dihadapan Notaris}

Akta PPJB yang dibuat oleh notaris pada dasarnya merupakan akta otentik yang tidak akan disengketakan apabila salah satu pihak tidak merasa dirugikan, tetapi dengan adanya isi perjanjian didalam PPJB yang memuat hal-hal yang telah disebutkan diatas, maka dapat timbul suatu permaslahan karena salah satu pihak merasa dirugikan oleh pihak lainnya. Adapun isi perjanjian yang penting untuk dibahas secara rinci adalah mengenai hak dan kewajiban antara penjual dan pembeli, harga obyek jual beli dan tata cara pembayaran. Klausul tersebut dapat memberikan kepastian hukum bagi para pihak setelah menghadap ke notaris. Perumusan jangka waktu didalam akta disebutkan mengenai kapan pembeli akan melunasi dengan jangka waktu yang telah tertulis di dalam akta, dan juga mengenai waktu kelengkapan persyaratan yang harus dilengkapi sebelum akta Perjanjian Pengikatan Jual Beli (PPJB) dibuat.

Perlindungan hukum dalam akta Perjanjian Pengikatan Jual Beli (PPJB) dapat dirumuskan sendiri oleh calon penjual, biasanya berupa persyaratan yang biasanya dimintakan sendiri oleh calon penjual itu sendiri. Misalnya ada calon penjual yang didalam Perjanjian Pengikatan JualBeli (PPJB) yang dibuatnya memintakan kepada pihak pembeli agar melakukan pembayaran uang pembeli dengan jangka waktu tertentu yang disertai dengan syarat batal dan sanksi apabila terlambat membayar, ada pula yang apabila pembeli tidak memenuhi pembayaran sebagaimana telah dimintakan dan disepakati maka Perjanjian Pengikatan Jual Beli (PPJB) hak atas tanah yang telah dibuat dan disepakati menjadi batal dan biasanya pihak penjual tidak akan mengambilkan uang yang telah dibayarkan kecuali pihak pembeli meminta pengecualian.Kebijakan yang dibuat oleh penjual tersebut adalah salah satu sanksi yang diberikan kepada calon pembeli bahwa dia tidak dapat memenuhi kewajibannya. ${ }^{23}$

Berbeda dengan perlindungan terhadap calon penjual, perlindungan terhadap pembeli biasanya selain dilakukan dengan persyaratan juga di ikuti dengan permintaan pemberian kuasa yang tidak dapat ditarik kembali.Tujuannya adalah apabila pihak penjual tidak memenuhinya maka pihak pembeli dapat menuntut dan memintakan ganti rugi sesuai dengan kesepakatan yang diatur dalam Perjanjian Pengikatan Jual Beli (PPJB). Selain itu perlindungan lain adalah dengan perjanjian pemberian kuasa yang tidak dapat ditarik kembali apabila semua persyaratan telah

\footnotetext{
23 Made Gede Arthadana, Akibat Hukum Pembatalan Akta Pengikatan Jual Beli Terhadap Biaya Yang Ditimbulkan Dihadapan Notaris, diakses pada tanggal 27 Januari 2020 pada laman file://Users/admin/Downloads/536-Article\%20Text-10161-10-20180219.pdf
} 
terpenuhi untuk melakukan jual beli, maka pihak pembeli dapat melakukan pemindahan hak kepada dirinya sendiri ataupun ke orang lain walaupun pihak penjual tidak hadir dalam penandatanganan Akta Jual Beli. ${ }^{24}$

Berdasarkan ketentuan hukum yang berlaku sebagaimana yang tertuang dalam Pasal 1320 KUH Perdata, maka suatu perjanjian dinyatakan sah apabila telah memenuhi empat syarat yaitu :

a. Sepakat mereka yang mengikat dirinya;

b. Kecakapan bertindak untuk membuat suatu perjanjian;

c. Adanya objek atau suatu hal tertentu; dan

d. Suatu sebab yang halal

Dua syarat yang pertama, dinamakan syarat subyektif, karena mengenai orang-orangnya atau subyeknya yang mengadakan perjanjian, sedangkan dua syarat yang terakhir dinamakan syarat-syarat obyektif karena mengenai perjanjiannya sendiri atau obyek dari perbuatan hukum yang dilakukan itu.

Terdapat implikasi hukum jika salah satu syarat tersebut tidak terpenuhi.Dalam hal ini jika syarat obyektif tidak terpenuhi, perjanjian itu batal demi hukum. Artinya semula tidak pernah dilahirkan suatu perjanjian dan tidak pernah ada suatu perikatan.Dengan demikian, maka tidak ada dasar bagi para pihak untuk saling menuntut didepak hakim (null and void).Berkenaan syarat subyektif, jika syarat tidak terpenuhi maka perjanjian bukan batal demi hukum, tetapi salah satu pihak mempunyai hak untuk meminta supaya perjanjian itu dibatalkan.Maka pihak yang meminta pembatalan itu adalah pihak yang tidak cakap.Perjanjian yang demikian dinamakan voidable/vernietigbaar. ${ }^{25}$

Perjanjian Pengikatan Jual Beli (PPJB) atas condominium yang dibuat oleh para pihak dihadapan notaris dapat dimintakan pembatalan apabila salah satu pihak merasa dirugikan.

Ganti rugi dalam hukum perdata dapat timbul dikarenakan wanprestasi akibat dari suatu perjanjian atau dapat timbul dikarenakan oleh perbuatan melawan hukum. Ganti rugi yang muncul dari wanprestasi adalah jika ada pihak-pihak dalam perjanjian yang tidak melaksanakan komitmennya yang sudah dituangkan dalam perjanjian, maka menurut hukum dia dapat dimintakan tanggung jawabnya, jika pihak lain dalam perjanjian tersebut menderita kerugian karenanya.

Apabila PPJB dimintakan pembatalan, tentunya akan ada akibat hukum terhadap akta PPJB tersebut. Selain itu, yang perlu diketahui adalah bagaimana perlindungan hukum apabila pihak pembeli yang membatalkan PPJB begitupun sebaliknya.Seperti sanksi administrasi.

Sanksi administrasi merupakan perbuatan Pemerintah guna mengakhiri suatu keadaan yang dilarang oleh kaidah hukum administrasi atau melakukan apa yang seharusnya ditinggalkan oleh para warga masyarakat karena bertentangan dengan undang-undang atau

\footnotetext{
${ }^{24} \mathrm{Ibid}$

${ }^{25}$ Subekti, Op. it., hlm. 20.
} 
aturan hukum lainnya. ${ }^{26}$

Jika para pihak baik developer ataupun konsumen condominium memilih menyelesaikan suatu sengketa di pengadilan, maka jika pembeli yang mengajukan gugatan pihak pembeli harus sebisa mungkin membuktikan bahwa lawannya (developer/pengembang) tersebut telah melakukan wanprestasi, bukan keadaan memaksa (overmacht).Begitu pula dengan developer, developer harus meyakinkan hakim jika kesalahan bukan terletak padanya dengan pembelaan seperti keadaan memaksa, menyatakan bahwa pihak pembeli telah melepaskan haknya, dan kelalaian pembeli.Terhadap kelalaian atau kealpaan si berutang (si berutang atau pihak pembeli sebagai pihak yang wajib melakukan sesuatu), diancamkan beberapa sanksi atau hukuman. Hukuman atau akibat-akibat yang diterima oleh debitur yang lalai ada empat macam, yaitu: ${ }^{27}$

1. Membayar kerugian yang diderita oleh kreditur atau dengan singkat dinamakan ganti-rugi.

2. Pembatalan perjanjian atau juga dinamakan pemecahan perjanjian.

3. Peralihan risiko.

4. Membayar biaya perkara, kalau sampai diperkarakan didepan hakim.

Terkait dengan pihak yang dinyatakan harus membayar denda akibat batalnya PPJB tersebut, maka seharusnya dibuktikan dulu unsur-unsur sebagaimana tersebut diatas.Apabila pihak yang dinyatakan wanprestasi telah memenuhi keempat unsur diatas, maka pihak yang dinyatakan anprestasi tersebut wajib untuk emmberikan ganti kerugian.Oleh karenanya, dalam suatu PPJB harus disebutkan dengan jelas mengenai sanksi yang dierikan jika salah satu pihak dinyatakan wanprestasi.Hal ini sebagai pencegahan apabila dikemudian hari terdapat sengketa diantara para pihak. Maka, akibat yang ditimbulkan akibat batalnya PPJB yang dibuat dihadapan notaris karena wanprestasi adalah:

1. Adanya denda yang harus dibayarkan oleh pihak yang melakukan tindakan wanprestasi.

2. Akta yang dibuat dihadapan notaris yaitu akta PPJB menjadi dapat dibatalkan apabila tidak memenuhi unsur subyektif atau batal demi hukum apabila tidak memenuhi unsur obyektif.

3. Membayar biaya perkara apabila pembatalan PPJB tersebut dilakukan dimuka pengadilan.

\section{Penutup}

\section{Kesimpulan}

1. Penyebab batalnya Perjanjian Pengikatan Jual Beli (PPJB) tersebut dapat terjadi baik dikarenakan oleh pihak konsumen ataupun pihak developer. Adapun hal-hal yang dapat menyebabkan pembatalan PPJB yang dibuat dihadapan notaris yang berasal dari pihak developer adalah Pihak developer tidak melakukan kewajibannya untuk memberikan prestasi yang telah disepakati oleh kedua belah pihak, sehingga pihak developer tidak

\footnotetext{
${ }^{26}$ Bahder Johan Nasution, "Penerapan Sanksi Administratif Sebagai Sarana Pengendali Pembatasan Terhadap Kebebasan Bertindak Bagi Notaris", Recital Review Vol 2 No. 1 Tahun 2020, hlm. 4.

${ }^{27}$ Yahya Harahap, Segi-segi Hukum Perjanjian, Cetakan Kedua, Alumni, Bandung, 1986. hlm. 56.
} 
melakukan kewajibannya sebagaimana ternyata didalam Undang-Undang, maka pihak konsumen akan meminta ganti rugi kepada pihak developer. Namun, apabila diantara kedua belah pihak tidak mendapatkan solusi dari permasalahan tersebut, maka pihak yang dirugikan dapat menggugat pihak yang menyebabkan kerugian tersebut di pengadilan atau dengan membatalkan kesepakatan yang telah dibuat oleh para pihak. Selain itu, penyebab lain dapat berasal dari pihak Konsumen yang lalai dalam melakukan kewajibannya untuk membayar unit condominium yang telah disepakati didalam Perjanjian Pengikatan Jual Beli (PPJB) yang dibuat dihadapan notaris. Kewajiban-kewajiban yang tertulis di dalam Perjanjian Pengikatan Jual Beli (PPJB) antara kedua belah pihak harus dilaksanakan karena apabila tidak dilaksanakan, maka dapat menimbulkan suatu permasalahan diantara para pihak. Dikarenakan Konsumen tidak melakukan pembayaran sebagaimana diperjanjikan didalam Perjanjian Pengikatan Jual Beli (PPJB), dengan demikian Konsumen tersebut dapat dikatakan tidak memiliki itikad yang baik untuk memenuhi prestasinya, hal-hal inilah yang menyebabkan pihak developer merasa dirugikan oleh konsumen. Oleh karena masing masing pihak merasa dirugikan, maka hal tersebut dapat menjadi alasan batalnya Perjanjian Pengikatan Jual Beli (PPJB) atas condominium yang telah dibuat dihadapan notaris.

2. Akibat batalnya Perjanjian Pengikatan Jual Beli (PPJB) yang dibuat dihadapan notaris karena wanprestasi dapat menyebabkan batalnya akta yang dibuat dihadapan notaris yaitu akta Perjanjian Pengikatan Jual Beli (PPJB) dapat dibatalkan apabila tidak memenuhi unsur subyektif atau batal demi hukum apabila tidak memenuhi unsur obyektif sebagaimana ternyata didalam Pasal 1320 KUH Perdata yang menyatakan tentang syarat sahnya perjanjian. Selain batalnya akta yang dibuat dihadapan notaris, ada pula hal yang harus dibayarkan oleh pihak yang melakukan wanprestasi yaitu denda yang harus dibayarkan oleh pihak yang melakukan tindakan wanprestasi dengan membayar biaya ganti kerugian dan bunga yang ditimbulkan akibat wanprestasi tersebut, namun apabila perkara tersebut dilakukan dimuka pengadilan, maka harus membayar biaya perkara sesuai dengan putusan pengadilan.

\section{Saran}

1. Notaris sebagai pejabat umum yang berwenang membuat akta otentik harus menjalankan kewajibannya sesuai dengan peraturan perundang-undangan yang berlaku. Dalam hal membuat akta otentik notaris diharapkan dapat merumuskan secara rinci mengenai isi akta yang telah dibuat dan menjelaskan serta membacakan maksud dari isi akta tersebut, sehingga dapat meminimalisir perbuatan wanprestasi antara para pihak karena semua aturan yang terdapat dalam akta dapat dijadikan sebagai tindakan preventif sudah tertulis didalam akta otentik yang dibuat oleh notaris dihadapan para pihak.

2. Calon pembeli condominium diharapkan memahami isi dari perjanjian awal yang dibuat antara calon pembeli dan pihak developer dan juga akta Perjanjian Pengikatan Jual Beli (PPJB) sebagai perjanjian yang mengikat antara calon pembeli dan pihak developer. Sebelum dilakukan penandatanganan akta Perjanjian Pengikatan Jual Beli (PPJB) oleh 
para pihak dihadapan notaris, maka calon pembeli condominium harus menanyakan halhal terkait apa yag akan diperjanjikan, jika ada hal yang tidak dapat dipahami maka calon pembeli bisa menanyakan kepada pejabat yang berwenang membuat akta tersebut yaitu notaris. Dengan melakukan hal ini, maka dapat diketahui sanksi apabila pihak developer melakukan wanprestasi kepada calon pembeli.

3. Pengembang (developer) sebagai pihak penjual unit condominium diharapkan menjelaskan secara jelas dan terperinci mengenai isi dari perjanjian yang dibuat oleh pihak pengembang dan calon pembeli condominium, dengan menjelaskan isi dari perjanjian maka pihak pembeli dapat memahami isi dari perjanjian kedua belah pihak. Apabila terjadi wanprestasi oleh calon pembeli, maka calon pembeli telah memahami ada sanksi apabila terjadi wanprestasi oleh pihak pembeli. Selain itu, pengembang harus mentaati peraturan-peraturan terkait pemasaran condominium. Dengan demikian, diharapkan pihak developer dapat menghindari hal-hal yang menyebabkan adanya perbuatan wanprestasi.

\section{Daftar Pustaka}

\section{Buku}

Arie. S. Hutagalung, Kondominium Dan Permasalahnya (Edisi Revisi), BadanPenerbitkan Fakultas Hukum UI, Jakarta, 2017.

Lili Rasjidi dan I.B Wysa Putra, Hukum Sebagai Suatu Sistem,Remaja Rusdakarya, Bandung, 1993.

Maria Theresia Geme, Perlindungan Hukum Terhadap Masyarakat Hukum Adat Dalam Pengelolaan Cagar Alam Watu Ata Kabupaten Ngada, Provinsi Nusa Tenggara Timur,

Disertasi Program Doktor Ilmu Hukum Universitas Brawijaya Malang, 2012.

Salim HS, Pengantar Hukum Perdata Tertulis (BW), Cet, 3, Sinar Grafika, Jakarta, 2005.

Salim H.S, Perkembangan Hukum Kontrak Innominat di Indonesia, Sinar Grafika, Jakarta, 2003. Sugiharti,Tinjauan Yuridis Kontrak Baku Perjanjian Perikatan Jual Beli Rumah Susun/ Apartemen Taman Melati Sinduadi Di Kota Yogyakarta, Universitas Gajah Mada, 2007.

\section{Peraturan}

Kitab Undang-Undang Hukum Perdata.

Undang-Undang Nomor 2 Tahun 2014 tentang Perubahan atas Undang-Undang Nomor 30 Tahun 2004 tentang Jabatan Notaris Notaris.

Undang-UndangNomor 20 Tahun 2011 tentang Rumah Susun.

Peraturan Menteri PUPR Nomor 11/PRT/M/2019 tentang Sistem PPJB Rumah

Jurnal

Adrian Sutedi, Hukum Rumah Susun \& Apartemen, Sinar Grafika,Jakarta Timur 2010.

Alhamidy, Fauzan Aziman, Isis Ikhwansyah, Zainal Muttaqin, "Perlindungan Hukum Konsumen Akibat Pencabutan Izin Mendirikan Bangunan Apartment", Recital Review, Vol 2 No. 1, Januari 2020.

Aman, "Perlindungan Hukum Bagi Notaris dalam Melaksanakan Jabatannya", Recital Review, Vol 1 No. 2, Juli 2019, 
Bahder Johan Nasution, "Penerapan Sanksi Administratif Sebagai Sarana Pengendali Pembatasan Terhadap Kebebasan Bertindak Bagi Notaris", Recital Review Vol 2 No. 1,Januari2020.

Nindyo Pramono,"Problematika Putusan Hakim dalam perkara Pembatalan Perjanjian," Membar Hukum Volume 22 Nomor 1, Juni 2010.

Pingkan Martina Manueke,'Jual Beli Tanah Yang Mempunyai Sertifikat Hak Atas Tanah Menurut Peraturan Pemerintah Nomor 24 Tahun 1997',Lex Privatum, VI (2018).

\section{Internet}

https://id.wikipedia.org/wiki/Daftar_negara_menurut_jumlah_penduduk http://www.hukumproperti.com https://www.cnnindonesia.com/ekonomi/20180718160249-92-315126/kuartal-ii-penjualan-

kondominium-di-jabodetabek-melesu

https://www.hukumonline.com/berita/baca/lt5a20010d8395b/kenali-model-akad-ini-sebelumbeli-apartemen/

https://www.hukumonline.com/berita/baca/lt599ab7314a829/mengakhiri-konflik-konsumenpengembang-apartemen-oleh--riki-perdana-raya-waruwu/

file:///Users/admin/Downloads/536-Article\%20Text-1016-1-10-20180219.pdf 